\title{
Population Studies of Birds, by David Lack, FRS. Clarendon Press, 63s.
}

In the great debate on the causes of fluctuations in animal populations that has been in progress for the past 30 or 40 years, David Lack has assumed the mantle of defender of the Darwinian citadel. His chief antagonists have been the two Australian scientists Andrewartha and Birch, and V. C. Wynne-Edwards, Professor of Natural History at the University of Aberdeen, who in 1954 and 1962 respectively, put forward mutually antithetical alternatives to Lack's last (1954) broadside, The Natural Regulation of Animal Numbers. The present volume is Lack's rejoinder, based on the dozen or so long-term studies of bird populations which have become available since his last book.

It must be admitted that, granted his premises, he sweeps the board. Clearly, and Wynne-Edwards admits this too, food is the basic controlling factor in animal populations. The argument with Wynne-Edwards is: to what extent do animal populations normally reach the stage when food becomes a controlling factor? Here Wynne-Edwards puts himself beyond the Darwinian pale by hypothecating group-selection, a method of evolution not explicable within the Darwinian canon, and admittedly lacking any concrete evidence in its favour. (Lack also admits there is still precious little concrete evidence for his own views.) Andrewartha and Birch, on the other hand, working on insects, not birds, do not believe at all in the control of anlimal populations by density-dependent factors such as food supply.

The best comment on this great debate is Charles Elton's in The Pattern of Animal Communities, which I reviewed in the last issue of ORYX (p. 320): "The whole field of population control in nature and theories about how it works has got into a rather peculiar state where a number of strongly held views exist that are at first sight incompatible with one another ... What is needed now in animal ecology is a sort of Ecumenical movement, or more precisely the development of a general comparative ecology of population limitation."

David Lack, I fear, is too much of a Pope to be a real Ecumenist, but the field is wide open to somebody-why not Charles Elton himself?-who knows that when a number of scientists hold strongly to apparently antithetical views, they are probably mostly right in the positive parts of their theories, but mostly wrong in refusing to concede some right to their opponents, and that the truth lies somewhere in between.

\section{RICHARD FITTER}

\section{The Snowdonia National Park, by W. M. Condry. Collins, New Naturalist, 30s.}

The name of "Bill" Condry is well known not only in Wales but far outside it, and ramblers and naturalists alike will turn with interest to his account of one of the most rugged and attractive of the National Parks in Britain. Having defined Snowdonia as stretching from Conway southward to Abendovey, and from rather east of Bala to beyond Tremadoc in the west, he begins with a chapter on past visitors to the area-Giraldus, Leland, Lhuyd among the earlier ones and numerous successors in the eighteenth and early nineteenth centuries. Chapter 2, on "Rocks, Lands \& Forests", is mainly geological, while succeeding chapters deal with the plants, birds, the rest of the fauna, and nature reserves and conservation. 